\title{
Unexplored Refugia with High Cover of Scleractinian Leptoseris spp. and Hydrocorals Stylaster flabelliformis at Lower Mesophotic Depths (75-100 m) on Lava Flows at Reunion Island (Southwestern Indian Ocean)
}

\author{
Ludovic Hoarau 1,2,3,*(D) Héloïse Rouzé ${ }^{3,4,5}$, Émilie Boissin 3,4,5 (D), Nicole Gravier-Bonnet ${ }^{5,6}$, Patrick Plantard ${ }^{5}$, \\ Camille Loisil $^{5}$, Lionel Bigot ${ }^{1,3}$, Pascale Chabanet ${ }^{1,3}$, Priscille Labarrère ${ }^{2}$, Lucie Penin ${ }^{1,3}$, Mehdi Adjeroud ${ }^{1,3}$ (D) \\ and Thierry Mulochau ${ }^{6,7}$ \\ 1 UMR ENTROPIE, Université de La Réunion, IRD, CNRS, IFREMER, UNC, 97744 Saint Denis CEDEX 9, \\ La Réunion, France; lionel.bigot@univ-reunion.fr (L.B.); pascale.chabanet@ird.fr (P.C.); \\ lucie.penin@univ-reunion.fr (L.P.); mehdi.adjeroud@ird.fr (M.A.) \\ 2 GPMDLR, 2 rue Evariste De Parny, 97420 Le Port, La Réunion, France; priscille.labarrere@reunion.port.fr \\ 3 Laboratoire d'Excellence "CORAIL", 52 Avenue Paul Alduy, 66860 Perpignan, France; \\ heloise.rouze@gmail.com (H.R.); eboissin@gmail.com (É.B.) \\ 4 PSL Université Paris, CNRS-EPHE-UPVD, CRIOBE USR3278, 66860 Perpignan, France \\ check for \\ updates \\ Citation: Hoarau, L.; Rouzé, H.; \\ Boissin, É.; Gravier-Bonnet, N.; \\ Plantard, P.; Loisil, C.; Bigot, L.; \\ 5 Poisson Lune, 4 rue Benjamin Hoarau, 97430 Le Tampon, La Réunion, France; \\ nickygravier@yahoo.fr (N.G.-B.); poissonlune974@gmail.com (P.P.); camille.loisil@gmail.com (C.L.) \\ 6 Vie Océane, 6, avenue d'Aquitaine, 97427 Étang-Salé, La Réunion, France; biorecif@gmail.com \\ 7 BIORECIF, 3 ter rue de l'Albatros, 97434 Saint-Paul, La Réunion, France \\ * Correspondence: ludovic-remy.hoarau@univ-reunion.fr or ludovic.remy.hoarau@gmail.com
} Chabanet, P.; Labarrère, P.; Penin, L.; et al. Unexplored Refugia with High Cover of Scleractinian Leptoseris spp. and Hydrocorals Stylaster flabelliformis at Lower Mesophotic Depths (75-100 $\mathrm{m}$ ) on Lava Flows at Reunion Island (Southwestern Indian Ocean). Diversity 2021, 13, 141. https:/ / doi.org/10.3390/d13040141

Academic Editors: Bert W. Hoeksema, Hudson Tércio Pinheiro and Gal Eyal

Received: 27 February 2021

Accepted: 22 March 2021

Published: 25 March 2021

Publisher's Note: MDPI stays neutral with regard to jurisdictional claims in published maps and institutional affiliations.

Copyright: (c) 2021 by the authors. Licensee MDPI, Basel, Switzerland. This article is an open access article distributed under the terms and conditions of the Creative Commons Attribution (CC BY) license (https:/ / creativecommons.org/licenses/by/ $4.0 /)$.
Keywords: mesophotic coral ecosystem (MCEs); Reunion Island; lower mesophotic zone; scleractinian; hydrocoral; refugia; biodiversity; Southwestern Indian Ocean

Despite increased attention over the last decade on Mesophotic Coral Ecosystems (MCEs) [1-4], the lower mesophotic zone (60-150 m depth) characterized by low light levels, though still sufficient for coral growth and from which distinct benthic communities occur [4], remains poorly studied. MCEs are particularly understudied at Reunion Island and more broadly in the southwestern Indian Ocean where currently a limited number of studies document the benthic communities at these depths. However, a recent study highlighted the overlooked diversity in the southwestern Indian Ocean with the report of a new record of the scleractinian coral Leptoseris troglodyta $(65-90 \mathrm{~m})$ in caves of Mayotte [5]. In addition, studies on some complex mesophotic habitats occurring on lava flows (e.g., structure, environmental conditions) are still missing for a complete understanding of MCEs' biodiversity [6]. In Reunion Island where a frequent volcanic activity is recorded at the southeastern part of the island, both species diversity and composition of coral assemblages on lava flows at shallow depths (0-30 m depth) are distinct from typical coral reef sites located on the western and southern coast of Reunion Island [7].

Combined with recent scientific programs and citizen science actions (e.g., Poisson Lune Association) aiming to explore and assess the biodiversity of MCEs in Reunion Island, the lower mesophotic zone was recently investigated across the island coasts (seven sites from the North-West to the South-East) using closed circuit rebreather (CCR) diving. Two dives with two CCR trimix tech divers equipped with cameras were conducted in September 2020 at Sainte-Rose $\left(21^{\circ} 09^{\prime} 33^{\prime \prime}\right.$ S, $\left.55^{\circ} 50^{\prime} 10^{\prime \prime} \mathrm{E}\right)$, on the southeastern leeward coast of the island. Two dive stations $\sim 300 \mathrm{~m}$ apart from each other were investigated at depths 75-85 $\mathrm{m}$ and $90-100 \mathrm{~m}$ on a basaltic substrate, located nearby underwater lava flows from the eruptive event of 1977. Benthic assemblages were filmed (Supplementary Video S1), some specimens were collected for species identification, and fishes were filmed and photographed during 15-20-min dives (total bottom time). 
A mesophotic coral community consisting of significant coral cover and abundance of zooxanthellate scleractinian corals and azooxanthellate hydrocorals was discovered (Figure 1). The dominant benthic assemblage includes encrusting, foliaceous, and thin plate corals of the genus Leptoseris (Agariciidae) extending horizontally and of calcareous branching hydroids, commonly named lace corals (Stylasteriidae), belonging to Stylaster flabelliformis (Lamarck, 1816) erected vertically. Encrusting sponges, crustose coralline, macro and turf algae filled the rest of the available substrate space (Figure 1b-f). Leptoseris and Stylaster colonies were both abundant and densely aggregated with a visually estimated cover reaching up to $\sim 70-90 \%$ and $\sim 10-20 \%$, respectively. Leptoseris spp. formed horizontal large dark brown plates and tiers ( $>40 \mathrm{~cm}$ in diameter) while the white-pink fan-shaped Stylaster grows vertically in one plane above substrate crests (up to $60 \mathrm{~cm}$ tall), between Leptoseris plates and mostly perpendicularly to the main current direction (Figure 1c,d). Most corals were alive although some parts of some colonies of Stylaster were dead with their skeleton colonized with algae, sponges, and other hydroids (Figure 2a). The extent of this mesophotic benthic formation composed with Leptoseris spp. and Stylaster flabelliformis is estimated to be over $15,000 \mathrm{~m}^{2}$.

Our surveys with collected specimens revealed an extension of vertical range distribution of several coral species at Reunion Island with new maximum depth records (comparison with review in [8]). New depth records for Leptoseris hawaiiensis Vaughan, 1907 and Leptoseris scabra Vaughan, 1907 are reported for Reunion Island at 75-100 m depths, corals that were previously reported locally at $60 \mathrm{~m}$ and $70 \mathrm{~m}$ depths, respectively. According to Boschma [9], who studied previous literature and provided a precise description of S. flabelliformis while revising the collections of the Muséum National d'Histoire Naturel MNHN, S. flabelliformis is recorded from the Mascarene Islands of Mauritius and Reunion Island. Apart from the specimens collected in Mauritius and initially described by Lamarck (1816), the only others identified with certainty are those collected in Reunion Island at $292 \mathrm{~m}$ depth. The specimens were described with more details by Milne Edwards and Haime [10]. No more specimens were reported then in the scientific literature though Stylaster were documented during ROV surveys conducted between 100 and $400 \mathrm{~m}$ depths on the volcanic slopes of Reunion Island in 2009 [11]. Therefore, the colonies of S. flabelliformis collected at $95 \mathrm{~m}$ depth during the CCR dives are the first new specimens studied since the nineteenth century.

Zooxanthellate scleractinian corals are rarely found at dense aggregations at the lowest mesophotic depths. However, on rare occasions, the coral cover may be high at these depths. For instance, dense fields of up to $100 \%$ cover of Agaricia colonies were observed at 70-85 m depth at Curaçao [12] or a high cover of Leptoseris communities at Hawaiian Islands at 70-90 m depth [13,14], and a mixture of corals, Leptoseris, Pachyseris, and Montipora, on Myrmidon Reef (Great Barrier Reef) at $60 \mathrm{~m}$ depth [15]. Deep-water corals on young geological and prehistoric lava flows in Hawaii may also present large numbers and sizes of Coralliidae colonies [6]. This is the first documented record of such original benthic community composition with a high cover and size of both Leptoseris and Stylaster colonies on mesophotic lava flows. For S. flabelliformis, the spatial aggregation may be explained by its reproductive cycle and settlement pattern as it is a gonochoristic brooding species whose planula larvae are able to settle as soon as they leave the mother colony. The settlement of stylasterid larvae occurs on the available space, sheltered between and below the horizontal plates of Leptoseris or in small cavities of the bottom, as attested by the presence of small colonies (shown in Figure 1e,f). The presence of short-lived and non-dispersive larvae in their life cycle explains the high regional endemicity and limited distribution of stylasterid species worldwide as well as at the regional scale [16,17]. High densities of stylasterids providing structure-forming components as described herein were found in deep waters in the Straits of Florida and North Alaska, USA [18]. 

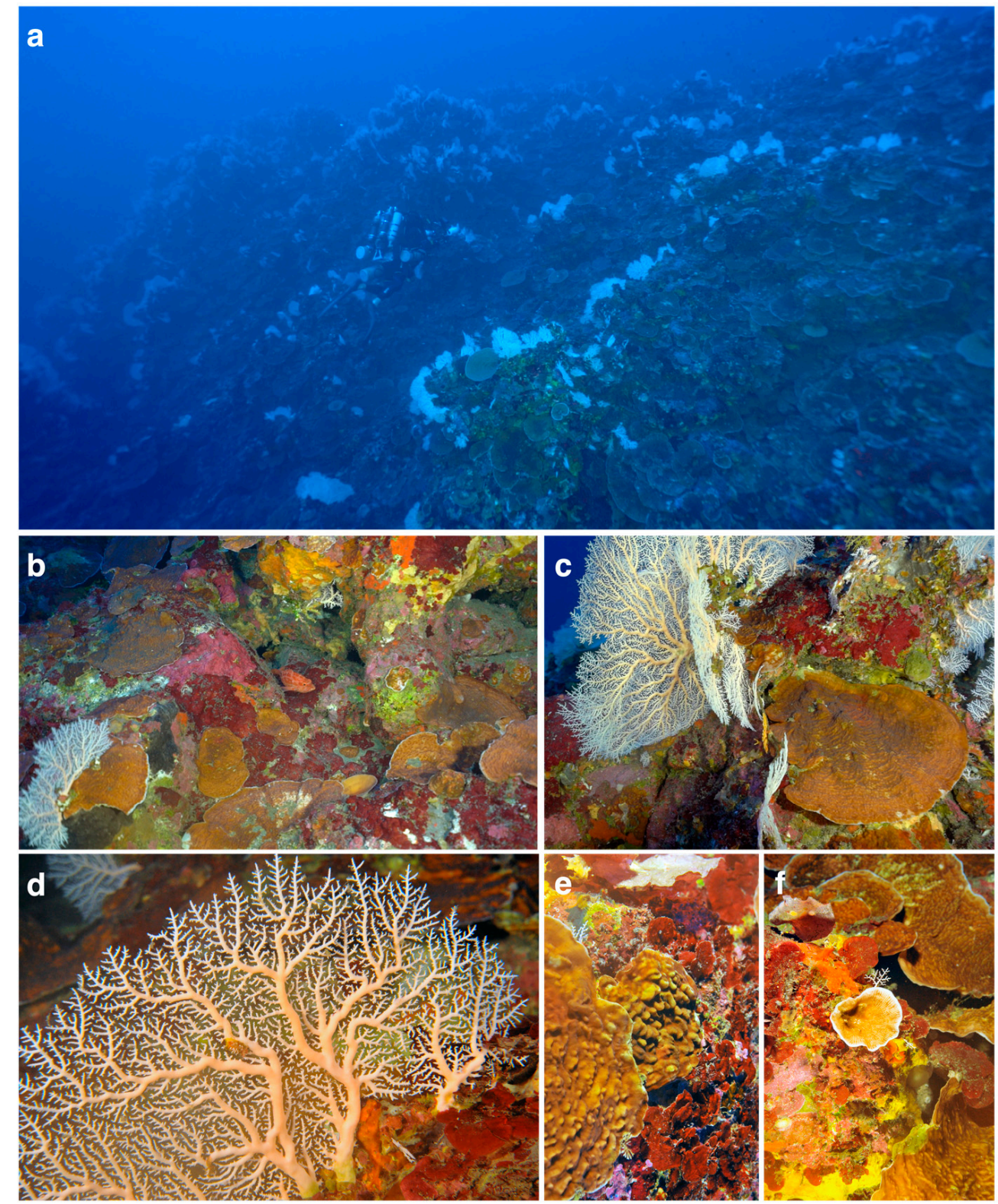

Figure 1. Benthic community on lava flow at 83-95 m depth on the leeward eastern coast of Reunion Island (Sainte-Rose) composed of dense aggregations of tall lace corals Stylaster flabelliformis and large zooxanthellate scleractinian corals Leptoseris spp. (a) Overall Mesophotic Coral Ecosystem (MCE) overview on the lava flow steep slope extending down to $100 \mathrm{~m}$ depth (Stylaster colonies in white). Close-up views of large plates of (b) Leptoseris spp. and (c) S. flabelliformis above a large plate and encrusting colonies of Leptoseris sp. along with sponges, crustose coralline, and turf and macro-algae. (d) Colony close-up view of $S$. flabelliformis. (e,f) The diversity of Leptoseris spp. composed with thin plates, encrusting, vases, and tiered colonies. 


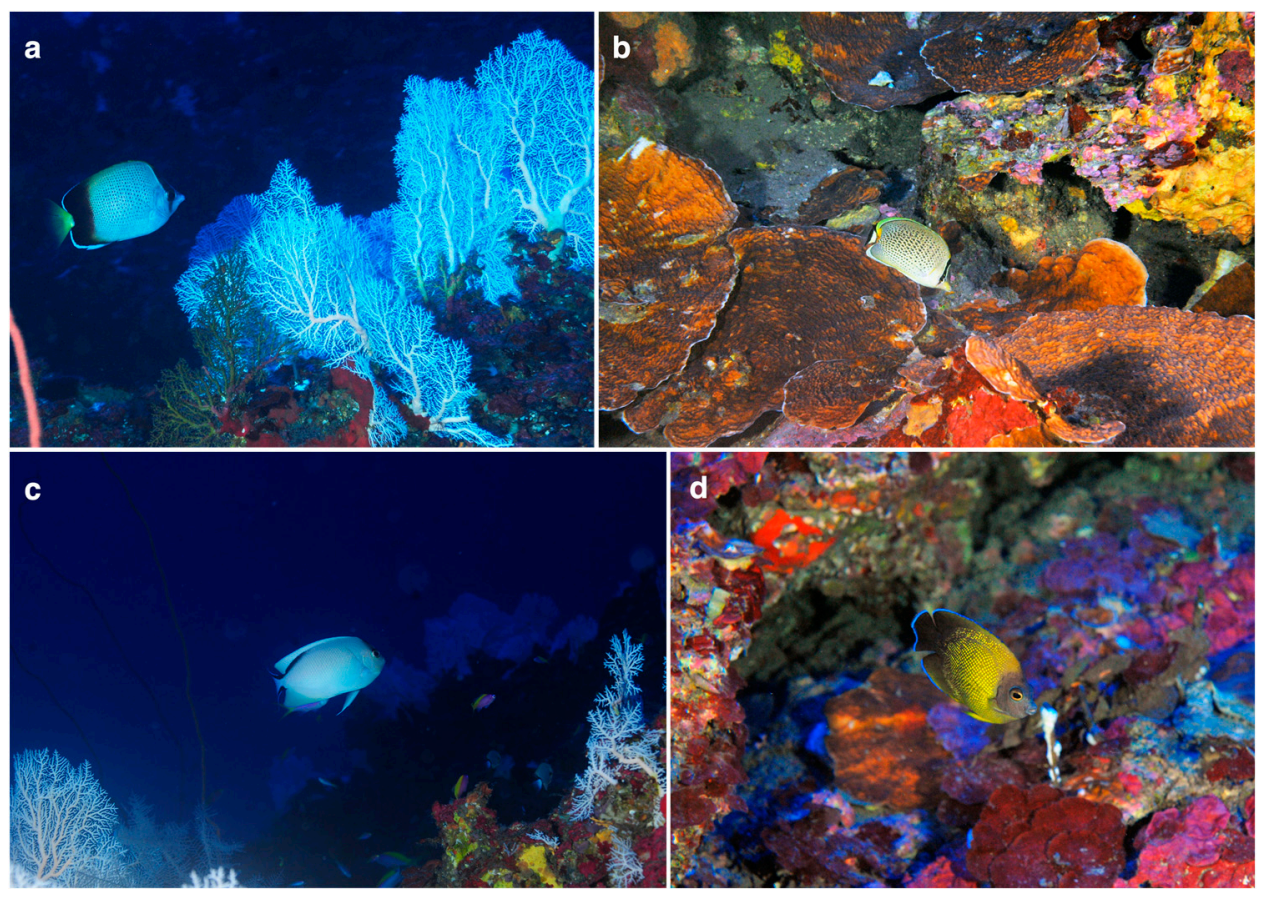

Figure 2. Some of the fishes associated to Leptoseris spp. and S. flabelliformis. (a) Chaetodon dolosus, (b) C. guttatissimus, (c) Genicanthus caudovittatus + with Pseudanthias evansi in the background, and (d) a rare endemic species angelfish species Apolemichthys guezei.

Such mesophotic coral assemblages on lava flow of Sainte-Rose constitutes a tridimensional complex structuring habitat providing shelter for benthic invertebrates and fish fauna. The numerous fish species observed in this mesophotic coral assemblage belong to (i) depth-generalist species ( 0 to $>60 \mathrm{~m}$ depth) common in the western Indian Ocean (e.g., Chaetodon dolosus Ahl, 1923 (Figure 2a)), (ii) Indo-Pacific species previously known with a more limited vertical distribution (e.g., Chaetodon guttatissimus Bennett, 1832 described until 0-25 m depth; Genicanthus caudovittatus (Günther, 1860) at 15-70 m depth in the western Indian Ocean; Pseudanthias evansi, (Smith, 1954) at 4-40 m depth in the Indian Ocean (Figure $2 b, c)$ ), and (iii) rare and endemic species from Reunion Island at depths of 60-80 m [19] to 90 m [20] (e.g., Apolemichthys guezei (Randall and Maugé, 1978) photographed at $95 \mathrm{~m}$ depth (Figure 2d)). These findings support a high potential of deep refugia for fish and invertebrates provided by the coral assemblage and highlight the distinctness of MCEs [1-4] that constitute relevant habitats for an underestimated number of species.

Our observations are preliminary results from scientific programs aimed at studying biodiversity, structure, and functioning of Reunion Island MCEs. More surveys should be conducted in the lower mesophotic zone as increasing sampling efforts would rapidly improve our knowledge on the ecology of species (i.e., their vertical distribution and habitats) and thus better determine their status for conservation. Given the limited number of CCR dives and time spent at lower mesophotic depths, original information regarding diversity and community structure of Reunion Island mesophotic corals and fishes were collected here through videos and photos, improving our understanding on these distinct ecosystems $[3,4]$. At the moment, no protection measures specifically target the lower depths of MCEs around Reunion Island. Adequate conservation tools should be implemented to protect these unique and fragile habitats as a mean to protect their structural complexity and associated underexplored biodiversity. 
Supplementary Materials: The following is available online at https:/ / www.mdpi.com/1424-2818/ 13/4/141/s1, Video S1: Video footage of coral communities on a steep slope lava flow at $85 \mathrm{~m}$ depth, Sainte-Rose, Reunion Island.

Author Contributions: Conceptualization and supervision, L.H., É.B., T.M., and M.A.; methodology, L.H.; validation, L.P., P.C., and M.A.; formal analysis, L.H., H.R., and É.B.; investigation, L.H., É.B., H.R., N.G.-B., C.L., P.P., and T.M.; writing-original draft preparation, L.H., H.R., É.B., and N.G.-B.; writing-review and editing, L.H., H.R., É.B., N.G.-B., L.B., L.P., P.C., and M.A.; project administration, T.M., P.L., L.P., and M.A.; funding acquisition, É.B., L.P., T.M., P.C., and M.A. All authors have read and agreed to the published version of the manuscript.

Funding: This research was conducted under the PhD fellowship CIFRE ANRT N²020/0283Funding for mesophotic depth exploration was obtained through a BEST grant (project MesoRun) and Inventaire National du Patrimoine Naturel (INPN) grant (project HydMeR) and was supported by both associations Vie Océane and Poisson Lune.

Institutional Review Board Statement: Not applicable.

Informed Consent Statement: Not applicable.

Acknowledgments: We thank Jean-Claude Martigné, Léo Broudic, Florence Trentin, and Daniel Boyer for providing us technical assistance and facilities on the field. We are very grateful to Lara Ainley for her valuable revision of the English and Michel Pichon for providing insights in coral identification. We also thank the three anonymous reviewers for their constructive comments.

Conflicts of Interest: The authors declare no conflict of interest. The funders had no role in the design of the study; in the collection, analyses, or interpretation of data; in the writing of the manuscript, or in the decision to publish the results.

\section{References}

1. Pyle, R.L.; Copus, J.M. Mesophotic coral ecosystems: Introduction and overview. In Mesophotic Coral Ecosystems; Loya, Y., Puglise, K.A., Bridge, T.C.L., Eds.; Springer: Cham, Switzerland, 2019; pp. 3-27.

2. Hinderstein, L.M.; Marr, J.C.; Martinez, F.A.; Dowgiallo, M.J.; Puglise, K.A.; Pyle, R.L.; Zawada, D.G.; Appeldoorn, R. Theme section on "Mesophotic coral ecosystems: Characterization, ecology, and management". Coral Reefs 2010, 29, 247-251. [CrossRef]

3. Rocha, L.A.; Pinheiro, H.T.; Shepherd, B.; Papastamatiou, Y.P.; Luiz, O.J.; Pyle, R.L.; Bongaerts, P. Mesophotic coral ecosystems are threatened and ecologically distinct from shallow water reefs. Science 2018, 361, 281-284. [CrossRef]

4. Lesser, M.P.; Slattery, M.; Laverick, J.H.; Macartney, K.J.; Bridge, T.C. Global community breaks at $60 \mathrm{~m}$ on mesophotic coral reefs. Glob. Ecol. Biogeogr. 2019, 28, 1403-1416. [CrossRef]

5. Pichon, M.; Rouzé, H.; Barathieu, G.; Konieczny, O.; Adjeroud, M.; Thomassin, B. Extension of the known distribution of the scleractinian coral Leptoseris troglodyta to the southwestern Indian Ocean: New record from mesophotic submarine caves in Mayotte. Bull. Mar. Sci. 2020, 96, 783-784. [CrossRef]

6. Putts, M.R.; Parrish, F.A.; Trusdell, F.A.; Kahng, S.E. Structure and development of Hawaiian deep-water coral communities on Mauna Loa lava flows. Mar. Ecol. Prog. Ser. 2019, 630, 69-82. [CrossRef]

7. Jouval, F.; Bigot, L.; Bureau, S.; Quod, J.-P.; Penin, L.; Adjeroud, M. Diversity, structure and demography of coral assemblages on underwater lava flows of different ages at Reunion Island and implications for ecological succession hypotheses. Sci. Rep. 2020, 10, 20821. [CrossRef] [PubMed]

8. Muir, P.R.; Pichon, M. Biodiversity of Reef Building Scleractinian Corals. In Mesophotic Coral Ecosystems; Loya, Y., Puglise, K.A., Bridge, T.C.L., Eds.; Springer: Cham, Switzerland, 2019; pp. 589-620.

9. Boschma, H. Stylasterina in the collection of the Paris Museum III. Stylaster flabelliformis (Lamarck). Zool. Med. Leiden 1957, 35, 261-282.

10. Milne Edwards, H.; Haime, J. Recherche sur les Polypiers. Mém. 5. Monographie des Oculinides. Ann. Sci. Nat. Zool. 1850, 13, 63-110.

11. Durville, P.; Mulochau, T.; Alayse, J.P.; Barrère, A.; Bigot, L.; Troadec, R. Exploration sous-marine à l'aide d'un engin de type R.O.V. sur les reliefs profonds de l'île de La Réunion expédition Abyssea. Rev. Ecol. (La Terre La Vie) 2009, 64, $293-304$.

12. Hoeksema, B.W.; Bongaerts, P.; Baldwin, C.C. High coral cover at lower mesophotic depths: A dense Agaricia community at the leeward side of Curaçao, Dutch Caribbean. Mar. Biodivers. 2017, 47, 67-70. [CrossRef]

13. Pochon, X.; Forsman, Z.H.; Spalding, H.L.; Padilla-Gamiño, J.L.; Smith, C.M.; Gates, R.D. Depth specialization in mesophotic corals (Leptoseris spp.) and associated algal symbionts in Hawai'i. R. Soc. Open Sci. 2015, 2, 140351. [CrossRef] [PubMed]

14. Pyle, R.L.; Boland, R.; Bolick, H.; Bowen, B.W.; Bradley, C.J.; Kane, C.; Kosaki, R.K.; Langston, R.; Longenecker, K.; Montgomery, A.; et al. A comprehensive investigation of mesophotic coral ecosystems in the Hawaiian Archipelago. PeerJ 2016, 4, e2475. [CrossRef] [PubMed] 
15. Bongaerts, P.; Muir, P.; Englebert, N.; Bridge, T.C.L.; Hoegh-Guldberg, O. Cyclone damage at mesophotic depths on Myrmidon Reef (GBR). Coral Reefs 2013, 32, 935. [CrossRef]

16. Ostarello, G.L. Natural history of the hydrocoral Allopora californica Verrill (1866). Biol. Bull. 1973, 145, 548-564. [CrossRef]

17. Cairns, S.D. Global Diversity of the Stylasteridae (Cnidaria: Hydrozoa: Athecatae). PLoS ONE 2011, 6, e21670.

18. Hourigan, T.F.; Lumsden, S.E.; Dorr, G.; Bruckner, A.W.; Brooke, S.; Stone, R.P. Deep Coral Ecosystems of the United States: Introduction and National Overview. In The State of Deep Coral Ecosystems in the United States; Lumsden, S.E., Hourigan, T.F., Bruckner, A.W., Dorr, G., Eds.; NOAA Technical Memorandum CRCP-3: Silver Spring, MD, USA, 2007; pp. 1-64.

19. Allen, G.R. Butterfly and Angelfishes of the World, 3rd ed.; Mergus Publishers: Melle, Germany, 1985; p. 254.

20. Tea, Y.-K.; Plantard, P.; Greene, B.D. Notes on fishes of the mesophotic reefs of Réunion Island. J. Ocean Sci. Found. 2020, 35, 1-7. 